\title{
Modified Method for Synthesis of 4-(Aryloxy)-5-(1-benzotryazolyl) Phthalonitriles
}

\author{
Serafima A. Znoyko, ${ }^{@}$ Vladimir E. Maizlish, Gennady P. Shaposhnikov, \\ Oksana N. Zubkova, and Anastasiya I. Savinova \\ Research Institute of Macroheterocycles, Ivanovo State University of Chemistry and Technology, 153000 Ivanovo, Russia \\ ${ }^{\circledR}$ Corresponding authorE-mail: znoykosa@yandex.ru
}

\begin{abstract}
An improved two-step method for the synthesis of 4-(aryloxy)-5-(1-benzotryazolyl)-phthalonitriles on the basis of 4-bromo-5nitrophthalonitrile was developed. It includes nucleophilic substitution of the bromine atom in 4-bromo-5-nitrophthalonitrile by aryloxy group on the first stage and then of nitro group by benzotriazolyl group on the second stage.
\end{abstract}

Keywords: Synthesis, phthalonitriles, benzotriazole.

\section{Модифицированный способ получения 4-(арилокси) -5-(1-бензотриазолил)фталонитрилов}

\author{
С. А. Знойко, ${ }^{@}$ В. Е. Майзлиш, Г. П. Шапошников, О. Н. Зубкова, А. И. Савинова \\ НИИ макрогетероциклических соединений, Ивановский государственный химико-технологический университет, \\ 153000 Иваново, Россия \\ ${ }^{\circledR}$ E-mail: znoykosa@yandex.ru
}

\begin{abstract}
Разработан упрощенный способ синтеза 4-(арилокси)-5-(1-бензотриазолил)-фталонитрилов из 4-бром5-нитрофталонитрила, включающий две стадии: нуклеофильное замещчение атома брома в 4-бром-5нитрофталонитриле оксиарильной группой, а затем нитрогруппы в 4-(арилокси)-5-нитрофталонитриле 1Нбензотриазолом.
\end{abstract}

Ключевые слова: Синтез, фталонитрилы, бензотриазол.

\section{Introduction}

Search and development of new and improvement of already known methods for synthesis of complex organic compounds is an important and actual problem of organic chemistry. Phthalonitrile and its derivatives as precursors for «nitrilic» method of synthesis of phthalocyanines are widely used. ${ }^{[1-4]}$ Substituted phthalocyanines combining different substituents on the same benzene rings have a special place among many phthalocyanine derivatives..$^{[1,3,5,6]}$ For example metal complexes of 1,8,15,22-tetrakis(phenylsulfanyl)-3,10, 17,24-tetrakis(tert-butyl)phthalocyanine with manganese chloride, zinc and aluminum hydroxide proposed as contrasting agent for magnetic-resonance diagnostic of tumors ${ }^{[7]}$ and immunoliposomal form of photosensitiser. ${ }^{[8]}$

Combination of benzotriazolyl and aryloxy fragments on the periphery of phthalocyanine molecule provides high solubility in organic solvents, ${ }^{[9]}$ thermo stability on air under high temperatures, ${ }^{[10]}$ liquid crystalline properties. $^{[11,12]}$ Furthermore these phthalocyanine derivatives readily form sulfo-derivatives ${ }^{[13]}$ and sulfochlorides ${ }^{[14]}$ at room temperature. This fact is very interesting for modification of physicochemical properties of benzotriazolyl substituted phthalocyanines. Synthesis of 2,9,16,23tetrakis(1-benzotriazolyl)-3,10,17,24-tetrakis-(aryloxy) phthalocyanines and their metal complexes was developed on the basis of corresponding disubstituted phthalonitriles. ${ }^{[10-14]}$ Three-stage process for preparation of these phthalonitriles with total duration of 5.5 hours was elaborated previously. ${ }^{[15,16]}$

The purpose of the study was a finding of simplified method for the synthesis of these compounds from 4-bromo5-nitrophthalonitrile which would reduce number of synthetic operations preserving synthetic yield. 


\section{Experimental}

Elemental analysis was performed on FlashEA 1112 instrument and IR spectra were recorded on Avatar 360 FT-IR ESP spectrophotometer. Chromato-mass-spectrum of compound 15 was fixed by ESI method on Saturn 2000K (GC-MS). ${ }^{1} \mathrm{H}$ NMR spectra of test solutions in $\mathrm{CDCl}_{3}$ with internal standard TMS were recorded on Bruker DRX-500. All analyzes were performed using Equipment Access Center of ISUCT.

Chemicals were purchased from Aldrich Chemicals $\mathrm{C}^{\circ}$ and used as received without purification.

4-Bromo-5-nitrophthalonitrile (1) was synthesized by known method. ${ }^{[17]}$

Synthesis of 4-(aryloxy)-5-nitrophthalonitriles (11-17). 4-Bromo-5-nitrophthalonitrile 1 ( $1 \mathrm{~g}, 3 \mathrm{mmol})$ and equimolar amounts of naphthols or phenol and their substituted derivatives were dissolved in $10 \mathrm{ml}$ of DMF and the solution of $0.46 \mathrm{~g}$ (3 $\mathrm{mmol}$ ) of potassium carbonate in $2 \mathrm{ml}$ of water was added. Reaction mixture was stirred for $25-35 \mathrm{~min}$ at $20-25^{\circ} \mathrm{C}$. The precipitate was filtered and washed with ethanol or 2-propanol until a colorless filtrate was obtained, then washed by water and dried at $70-80^{\circ} \mathrm{C}$.

4-Nitro-5-phenoxyphthalonitrile (11). Phenol (0.37 g) was used in the reaction. The product was washed by ethanol $(20 \mathrm{ml})$, then hot water $(100 \mathrm{ml})$ and dried $(0.99 \mathrm{~g}, 0.27 \mathrm{mmol}, 94 \%$ on phthalonitrile 1). Found, \%: C 63.57, H 2.58, N 18.03. $\mathrm{C}_{14} \mathrm{H}_{7} \mathrm{~N}_{3} \mathrm{O}_{3}$. Calculated, \%: C 63.40, H 2.66, N 18.10. IR (KBr) $v_{\max } \mathrm{cm}^{-1}: 2234$ $(\mathrm{C} \equiv \mathrm{N}), 1535$ (unsym. $\mathrm{NO}_{2}$ ), 1345 (symm. $\mathrm{NO}_{2}$ ), 1208 (Ar-O-Ar).

4-(4-Methylphenoxy)-5-nitrophthalonitrile (12). 4-Methylphenol $(0.38 \mathrm{~g})$ was used in the reaction. The product was washed by 2-propanol, then water until disappearing of the smell of 2-propanol and dried (1.06 g, $0.29 \mathrm{mmol}, 96 \%$ on phthalonitrile 1). Found, \%: $\mathrm{C} 64.20, \mathrm{H} 3.05, \mathrm{~N}$ 15.03. $\mathrm{C}_{15} \mathrm{H}_{9} \mathrm{~N}_{3} \mathrm{O}_{3}$. Calculated, \%: C 64.52, H 3.25, N 15.05. IR (KBr) $v_{\max } \mathrm{cm}^{-1}: 2985,2870$ $\left(\mathrm{CH}_{3}\right), 2232(\mathrm{C} \equiv \mathrm{N}), 1538$ (unsym. $\mathrm{NO}_{2}$ ), 1363 (symm. $\mathrm{NO}_{2}$ ), 1212 (Ar-O-Ar)

4-(4-tert-Butylphenoxy)-5-nitrophthalonitrile (13). 4-tertButylphenol $(0.45 \mathrm{~g})$ was used in the reaction. The product was washed by 2-propanol, then water until disappearing of the smell of 2-propanol and dried (1.15 g, $0.28 \mathrm{mmol}, 90 \%$ on phthalonitrile 1). Found, \%: $\mathrm{C} 67.20, \mathrm{H} 4.65, \mathrm{~N} 13.03 . \mathrm{C}_{18} \mathrm{H}_{15} \mathrm{~N}_{3} \mathrm{O}_{3}$. Calculated, \%: C 67.28, H 4.71, N 13.08. IR (KBr) $v_{\max } \mathrm{cm}^{-1}: 2985,2870\left(\mathrm{CH}_{3}\right), 2230$ $(\mathrm{C} \equiv \mathrm{N}), 1536$ (unsym. $\mathrm{NO}_{2}$ ), 1361 (symm. $\mathrm{NO}_{2}$ ), 1220 (Ar-O-Ar).

4-Nitro-5-(4-nitrophenoxy)phthalonitrile (14). 4-Nitrophenol $(0.46 \mathrm{~g})$ was used in the reaction. The product was washed by 2-propanol, then water until disappearing of the smell of 2-propanol and dried (1.06 g, $0.24 \mathrm{mmol}, 86 \%$ on phthalonitrile 1). Found, \%: C 54.00, H 1.95, N 18.03. $\mathrm{C}_{14} \mathrm{H}_{6} \mathrm{~N}_{4} \mathrm{O}_{5}$. Calculated, \%: C 54.20, $\mathrm{H}$ 1.95, N 18.06. IR (KBr) $v_{\text {max }} \mathrm{cm}^{-1}: 2232(\mathrm{C} \equiv \mathrm{N}), 1538$ (unsym. $\mathrm{NO}_{2}$ ), 1363 (symm. $\mathrm{NO}_{2}$ ), 1210 (Ar-O-Ar).

4-Nitro-5-(4-phenylphenoxy)phthalonitrile (15). 4-Phenylphenol $(0.51 \mathrm{~g})$ was used in the reaction. The product was washed by 2-propanol, then water until disappearing of the smell of 2-propanol and dried $(1.14 \mathrm{~g}, 0.26 \mathrm{mmol}, 85 \%$ on phthalonitrile 1). Found, \%: $\mathrm{C} 67.20, \mathrm{H} 4.65, \mathrm{~N} 13.03 . \mathrm{C}_{20} \mathrm{H}_{11} \mathrm{~N}_{3} \mathrm{O}_{3}$. Calculated, \%: C 67.28, H 4.71, N 13.08. IR (KBr) $v_{\max } \mathrm{cm}^{-1}: 2234(\mathrm{C} \equiv \mathrm{N}), 1538$ (unsym. $\mathrm{NO}_{2}$ ), 1367 (symm. $\mathrm{NO}_{2}$ ), 1210 (Ar-O-Ar).

4-(1-Naphthoxy)-5-nitrophthalonitrile (16). 1-Naphthol (0.46 g) was used in the reaction. The product was washed by 2-propanol, then water until disappearing of the smell of 2-propanol and dried (1.2 g, $0.28 \mathrm{mmol}, 92 \%$ on phthalonitrile 1). Found, \%: C 68.57, H 2.88, N 13.33; $\mathrm{C}_{18} \mathrm{H}_{9} \mathrm{~N}_{3} \mathrm{O}_{3}$; Calculated, \%: C 69.04, H 3.00, N 13.37 . IR (KBr) $v_{\max } \mathrm{cm}^{-1}: 2232(\mathrm{C} \equiv \mathrm{N}), 1538$ (unsym. $\mathrm{NO}_{2}$ ), 1365 (symm. $\left.\mathrm{NO}_{2}\right), 1204$ (Ar-O-Ar)

4-(2-Naphthoxy)-5-nitrophthalonitrile (17). 2-Naphthol (0.46 g) was used in the reaction. The product was washed by 2-propanol, then water until disappearing of the smell of 2-propanol and dried. $(1.1 \mathrm{~g}, 0.28 \mathrm{mmol}, 86 \%$ on phthalonitrile 1). Found, \%: C 68.57, H 2.88, N 13.33; $\mathrm{C}_{18} \mathrm{H}_{9} \mathrm{~N}_{3} \mathrm{O}_{3}$; Calculated, \%: C 69.07, H 2.95, N 13.45.
IR $(\mathrm{KBr}) v_{\max } \mathrm{cm}^{-1}: 2234(\mathrm{C} \equiv \mathrm{N}), 1536$ (unsym. $\mathrm{NO}_{2}$ ), 1367 (symm. $\mathrm{NO}_{2}$ ), 1218 (Ar-O-Ar).

Synthesis of 4-(1-benzotriazolyl)-5-(aryloxy)phthalonitriles (4-10). Synthesized on first stage 4-(aryloxy)-5-nitrophthalonitriles 11-17 $(2.7 \mathrm{mmol})$ and $0.40 \mathrm{~g}(2.7 \mathrm{mmol}) 1-H$-benzotriazole were dissolved in DMF $(10 \mathrm{ml})$ and a solution of $\mathrm{K}_{2} \mathrm{CO}_{3}(0.41 \mathrm{~g}, 2.7$ $\mathrm{mmol}$ ) in $2 \mathrm{ml}$ of water was added. Reaction mixture was stirred for $1 \mathrm{~h}$ at $65-70^{\circ} \mathrm{C}$. The precipitate was filtered and washed with 2-propanol, then water until colorless filtrate and disappearing of smell of 2-propanol, then dried at $70-80^{\circ} \mathrm{C}$.

4-(1-Benzotriazolyl)-5-phenoxyphthalonitrile (4). 4-Nitro-5phenoxyphthalonitrile $11(0.72 \mathrm{~g})$ was used in the reaction $(0.76 \mathrm{~g}$, $79 \%$ on 4-bromo-5-nitrophthalonitrile 1). M.p. $189-190^{\circ} \mathrm{C}$. Found, \%: C 71.56, H 3.21, N 20.25. $\mathrm{C}_{20} \mathrm{H}_{11} \mathrm{~N}_{5} \mathrm{O}$. Calculated, \%: C 71.32, H 3.25, N 20.10. IR (KBr) $v_{\text {max }} \mathrm{cm}^{-1}: 2235(\mathrm{C} \equiv \mathrm{N}), 1206$ (Ar-O-Ar), $1032(\mathrm{~N}=\mathrm{N}), 749(\mathrm{C}-\mathrm{N}) .{ }^{1} \mathrm{H}$ NMR $\left(\mathrm{CDCl}_{3}, 293 \mathrm{~K}\right) \delta_{\mathrm{H}} \mathrm{ppm}: 8.63(\mathrm{~s}$, $\left.1 \mathrm{H}, \mathrm{H}^{1}\right), 8.21\left(\mathrm{t}, 1 \mathrm{H}, \mathrm{H}^{3}\right), 8.16\left(\mathrm{~s}, 1 \mathrm{H}, \mathrm{H}^{2}\right), 8.02\left(\mathrm{~s}, 1 \mathrm{H}, \mathrm{H}^{6}\right), 7.80-7.78$ $\left(\mathrm{m}, 1 \mathrm{H}, \mathrm{H}^{4}\right), 7.51\left(\mathrm{t}, 1 \mathrm{H}, \mathrm{H}^{5}\right), 7.47-7.44\left(\mathrm{~m}, 1 \mathrm{H}, \mathrm{H}^{9}\right), 7.27\left(\mathrm{~d}, 2 \mathrm{H}, \mathrm{H}^{7}\right.$, $J=8.6 \mathrm{~Hz}), 7.20\left(\mathrm{~d}, 2 \mathrm{H}, \mathrm{H}^{8}, J=8.5 \mathrm{~Hz}\right)$.

4-(1-Benzotriazolyl)-5-(4-methylphenoxy)phthalonitrile (5). 4-(4-Methyl)-5-nitrophthalonitrile $12(0.75 \mathrm{~g})$ was used in the reaction. (0.78 g, 82\% on 4-bromo-5-nitrophthalonitrile 1). M.p. 225$227^{\circ} \mathrm{C}$. Found, \%: C 71.55, H 3.77, N 19.53. $\mathrm{C}_{21} \mathrm{H}_{13} \mathrm{~N}_{5} \mathrm{O}$. Calculated, \%: C 71.79, H 3.73, N 19.93. IR ( $\mathrm{KBr}) v_{\max } \mathrm{cm}^{-1}: 2985,2870\left(\mathrm{CH}_{3}\right)$, $2232(\mathrm{C} \equiv \mathrm{N}), 1212($ Ar-O-Ar), $1045(\mathrm{~N}=\mathrm{m}), 745(\mathrm{C}-\mathrm{N})$.

4-(1-Benzotriazolyl)-5-(4-tert-butylphenoxy)phthalonitrile (6). 4-(4-tert-Butylphenoxy)-5-nitrophthalonitrile 13 (0.87 g) was used in the reaction. (1.00 g, 73\% on 4-bromo-5-nitrophthalonitrile 1). M.p. $215-217^{\circ} \mathrm{C}$. Found, \%: C 73.25, H 4.75, N 17.78. $\mathrm{C}_{25} \mathrm{H}_{15} \mathrm{~N}_{5} \mathrm{O}$. Calculated, \%: C 73.27, H 4.86, N 17.80. IR (KBr) $v_{\max } \mathrm{cm}^{-1}: 2925,2890\left(\mathrm{CH}_{3}\right), 2232(\mathrm{C} \equiv \mathrm{N}), 1214(\mathrm{Ar}-\mathrm{O}-\mathrm{Ar}), 1045$ $(\mathrm{N}=\mathrm{N}), 746(\mathrm{C}-\mathrm{N}) .{ }^{1} \mathrm{H}$ NMR $\left(\mathrm{CDCl}_{3}, 293 \mathrm{~K}\right) \delta_{\mathrm{H}} \mathrm{ppm}: 8.75(\mathrm{~s}, 1 \mathrm{H}$ $\left.\mathrm{H}^{1}\right), 8.24\left(\mathrm{t}, 1 \mathrm{H}, \mathrm{H}^{3}\right), 8.15\left(\mathrm{~s}, 1 \mathrm{H}, \mathrm{H}^{2}\right), 8.04\left(\mathrm{~s}, 1 \mathrm{H}, \mathrm{H}^{6}\right), 7.69(\mathrm{~s}, 1 \mathrm{H}$, $\left.\mathrm{H}^{4}\right), 7.47-7.44\left(\mathrm{~m}, 1 \mathrm{H}, \mathrm{H}^{5}\right), 7.01\left(\mathrm{~d}, 2 \mathrm{H}, \mathrm{H}^{7}, J=8.5 \mathrm{~Hz}\right), 6.83(\mathrm{~d}, 2 \mathrm{H}$, $\left.\mathrm{H}^{8}, J=8.5 \mathrm{~Hz}\right), 1.33\left(\mathrm{~s}, 9 \mathrm{H}, \mathrm{CH}_{3}\right)$.

4-(1-Benzotriazolyl)-5-(4-nitrophenoxy)phthalonitrile (7). 4-(4-Nitrophenoxy)-5-nitrophthalonitrile $\mathbf{1 4}(0.92 \mathrm{~g})$ was used in the reaction. (1.07 g, 70\% on 4-bromo-5-nitrophthalonitrile 1). M.p. $189-191{ }^{\circ} \mathrm{C}$. Found, \%: C 62.55, H 2.36, N 21.27. $\mathrm{C}_{20} \mathrm{H}_{10} \mathrm{~N}_{6} \mathrm{O}_{3}$. Calculated, \%: C 62.83, H 2.64, N 21.98. IR (KBr) $v_{\max } \mathrm{cm}^{-1}: 2232$ $(\mathrm{C} \equiv \mathrm{N}), 1538$ (unsym. $\left.\mathrm{NO}_{2}\right), 1363$ (symm. $\left.\mathrm{NO}_{2}\right), 1212$ (Ar-O-Ar), $1045(\mathrm{~N}=\mathrm{N}), 746(\mathrm{C}-\mathrm{N}) .{ }^{1} \mathrm{H} \mathrm{NMR}\left(\mathrm{CDCl}_{3}, 293 \mathrm{~K}\right) \delta_{\mathrm{H}} \mathrm{ppm}: 8.78(\mathrm{~s}$, $\left.1 \mathrm{H}, \mathrm{H}^{1}\right), 8.23\left(\mathrm{t}, 1 \mathrm{H}, \mathrm{H}^{3}\right), 8.12\left(\mathrm{~s}, 1 \mathrm{H}, \mathrm{H}^{2}\right), 8.07-8.05\left(\mathrm{~d}, 2 \mathrm{H}, \mathrm{H}^{8}, J=\right.$ $8.5 \mathrm{~Hz}), 8.00\left(\mathrm{~s}, 1 \mathrm{H}, \mathrm{H}^{6}\right), 7.81\left(\mathrm{~m}, 1 \mathrm{H}, \mathrm{H}^{4}\right), 7.55\left(\mathrm{t}, 1 \mathrm{H}, \mathrm{H}^{5}\right), 7.28-7.26$ (d, $2 \mathrm{H}, \mathrm{H}^{7}, J=8.5 \mathrm{~Hz}$ ).

4-(1-Benzotriazolyl)-5-(4-phenylphenoxy)phthalonitrile (8). 4-(4-Phenylphenoxy)-5-nitrophthalonitrile $15(0.92 \mathrm{~g})$ was used in the reaction. (1.11 g, 73\% on 4-bromo-5-nitrophthalonitrile 1). M.p. $208-210^{\circ} \mathrm{C}$. Found, \%: C 73.25, $\mathrm{H} 4.75, \mathrm{~N} 17.80 . \mathrm{C}_{24} \mathrm{H}_{19} \mathrm{~N}_{5} \mathrm{O}$. Calculated, \%: C 73.27, H 4.87, N 17.80. IR (KBr) $v_{\max } \mathrm{cm}^{-1}: 2232$ $(\mathrm{C} \equiv \mathrm{N}), 1214$ (Ar-O-Ar), $1045(\mathrm{~N}=\mathrm{N}), 746(\mathrm{C}-\mathrm{N})$.

4-(1-Benzotriazolyl)-5-(1-naphthoxy)phthalonitrile (9). 4-(1-Naphthoxy)-5-nitrophthalonitrile $\mathbf{1 6}(1.10 \mathrm{~g})$ was used in the reaction. (1.10 g, 71\% on 4-bromo-5-nitrophthalonitrile 1). $m / z=387$. M.p. $210-212^{\circ} \mathrm{C}$. Found, \%: C 74.32, H 3.21, N 18.10 . $\mathrm{C}_{24} \mathrm{H}_{13} \mathrm{~N}_{5} \mathrm{O}$. Calculated, \%: C 74.41, H 3.30, N 18.08. IR (KBr) $v_{\max }$ $\mathrm{cm}^{-1}: 2230(\mathrm{C} \equiv \mathrm{N}), 1205\left(\right.$ Ar-O-Ar), $1045(\mathrm{~N}=\mathrm{N}), 745(\mathrm{C}-\mathrm{N}) .{ }^{{ }^{\max }} \mathrm{H}$ $\operatorname{NMR}\left(\mathrm{CDCl}_{3}, 293 \mathrm{~K}\right) \delta_{\mathrm{H}}$ ppm: $8.73\left(\mathrm{~s}, 1 \mathrm{H}, \mathrm{H}^{\mathrm{l}}\right), 8.23\left(\mathrm{t}, 1 \mathrm{H}, \mathrm{H}^{3}\right), 8.14$ $\left(\mathrm{s}, 1 \mathrm{H}, \mathrm{H}^{2}\right), 7.78-7.81\left(\mathrm{~m}, 1 \mathrm{H}, \mathrm{H}^{4}\right), 7.55-7.52\left(\mathrm{~m}, 3 \mathrm{H}, \mathrm{H}^{5,11,12}\right), 8.03(\mathrm{~s}$, $\left.1 \mathrm{H}, \mathrm{H}^{6}\right), 7.73-7.70\left(\mathrm{~m}, 1 \mathrm{H}, \mathrm{H}^{10}\right), 7.45-7.42\left(\mathrm{~m}, 1 \mathrm{H}, \mathrm{H}^{9}\right), 7.28-7.26(\mathrm{~m}$, $\left.1 \mathrm{H}, \mathrm{H}^{7}\right), 7.12\left(\mathrm{~s}, 1 \mathrm{H}, \mathrm{H}^{13}\right), 7.04-7.00\left(\mathrm{~m}, 1 \mathrm{H}, \mathrm{H}^{8}\right)$.

4-(1-Benzotriazolyl)-5-(2-naphthoxy) phthalonitrile (10). 4-(2-Naph-thoxy)-5-nitrophthalonitrile $17(1.10 \mathrm{~g})$ was used in the reaction. (1.06 g, $69 \%$ on 4-bromo-5-nitrophthalonitrile 1). $m / z=387(M=387)$. M.p. $210-212^{\circ} \mathrm{C}$. Found, \%: C 74.55 , H 3.08 $\mathrm{N}$ 18.23. $\mathrm{C}_{24} \mathrm{H}_{13} \mathrm{~N}_{3} \mathrm{O}$. Calculated, \%: C 74.41, H 3.30, N 18.08. IR $(\mathrm{KBr}) v_{\mathrm{c}} \mathrm{cm}^{-1}: 2232(\mathrm{C} \equiv \mathrm{N}), 1204(\mathrm{Ar}-\mathrm{O}-\mathrm{Ar}), 1045(\mathrm{~N}=\mathrm{N}), 746$ $(\mathrm{C}-\mathrm{N}) .{ }^{1} \mathrm{H}$ NMR $\left(\mathrm{CDCl}_{3}, 293 \mathrm{~K}\right) \delta_{\mathrm{H}} \mathrm{ppm}: 8.73\left(\mathrm{~s}, 1 \mathrm{H}, \mathrm{H}^{1}\right), 8.23$ $\left(\mathrm{t}, 1 \mathrm{H}, \mathrm{H}^{3}\right), 8.16\left(\mathrm{~s}, 1 \mathrm{H}, \mathrm{H}^{2}\right), 8.03\left(\mathrm{~s}, 1 \mathrm{H}, \mathrm{H}^{6}\right), 7.87-7.85(\mathrm{~m}, 2 \mathrm{H}$, 
$\left.\mathrm{H}^{11,12}\right), 7.81-7.78\left(\mathrm{~m}, 1 \mathrm{H}, \mathrm{H}^{4}\right), 7.68-7.65\left(\mathrm{~m}, 2 \mathrm{H}, \mathrm{H}^{8,9}\right), 7.55-7.52(\mathrm{~m}$, $\left.1 \mathrm{H}, \mathrm{H}^{5}\right), 7.45-7.41\left(\mathrm{~m}, 1 \mathrm{H}, \mathrm{H}^{10}\right), 7.33\left(\mathrm{~s}, 1 \mathrm{H}, \mathrm{H}^{13}\right), 7.16-7.13(\mathrm{~m}$, $\left.1 \mathrm{H}, \mathrm{H}^{7}\right)$.

\section{Results and Discussion}

Previously ${ }^{[15,16]}$ the three-stage method for preparation of 4-(aryloxy)-5-(1-benzotryazolyl)-phthalonitriles 4-10 from 4-bromo-5-nitrophthalonitrile 1 was elaborated (Scheme 1). On the first stage 4-(2-aminophenylamino)-5-nitrophthalonitrile $\mathbf{2}$ was synthesized by reaction of compound $\mathbf{1}$ with ortho-phenylenediamine in boiling isopropanole in the presence of triethylamine. On the second stage compound $\mathbf{2}$ was converted to 4-(1-benzotriazolyl)-5-nitrophthalonitrile $\mathbf{1 7}$ by diazotation and cyclization reaction in acetic acid media in the presence of sodium nitrite. Final stage was the reaction of compound $\mathbf{3}$ with aryloxy group in aqueous DMF in the presence of potassium carbonate. In this case the total duration of the synthesis was 5.5 hours.

Two-step formation of benzotriazolyl cycle was carried out due to the proton tautomerism of benzotriazole by the reaction with compound 1 . Consequently, the yield of the desired product 3 was decreased because 4-(1-benzotriazolyl)-5-(2- benzotriazolyl)phthalonitrile was formed as a by-product in the reaction mixture. ${ }^{[15]}$

Improved two-step method for the synthesis of 4-10 on the basis of $\mathbf{1}$ by consecutive nucleophilic substitution of bromine atom with naphthols or phenol and their derivatives at $20-25^{\circ} \mathrm{C}$ for $0.5 \mathrm{~h}$ and further substitution of nitro group by $1-H$-benzotriazole at $65-70^{\circ} \mathrm{C}$ for $1 \mathrm{~h}$ was developed (Scheme 2). Formation of 4-(aryloxy)-5-(2-benzotriazolyl)phthalonitriles was not observed on the second stage of the proposed method.

The yields of compounds 4-10 are kept at the level achieved by using of previously developed three-step procedure (Table 1). ${ }^{[15,16]}$

Influence of reaction conditions, particularly reaction temperature on the yield of substitution of nitro group by benzotriazolyl fragment was studied in the case of preparation of 4-(1-benzotriazolyl)-5-(2-naphthoxy)phthalonitrile (10). It was found that the best results were achieved at $65-70^{\circ} \mathrm{C}$. Heating of reaction mixture up to $100^{\circ} \mathrm{C}$ was accompanied by resin-like mass-formation. It was found that yield of compound 10 was reduced from $84 \%$ to $56 \%$ for reaction temperature of $50^{\circ} \mathrm{C}$ and further decreased to $13.6 \%$ for $30^{\circ} \mathrm{C}$. Apparently, deactivation of the nitro group in the intermediate $\mathbf{1 5}$ to nucleophilic aromatic substitution could

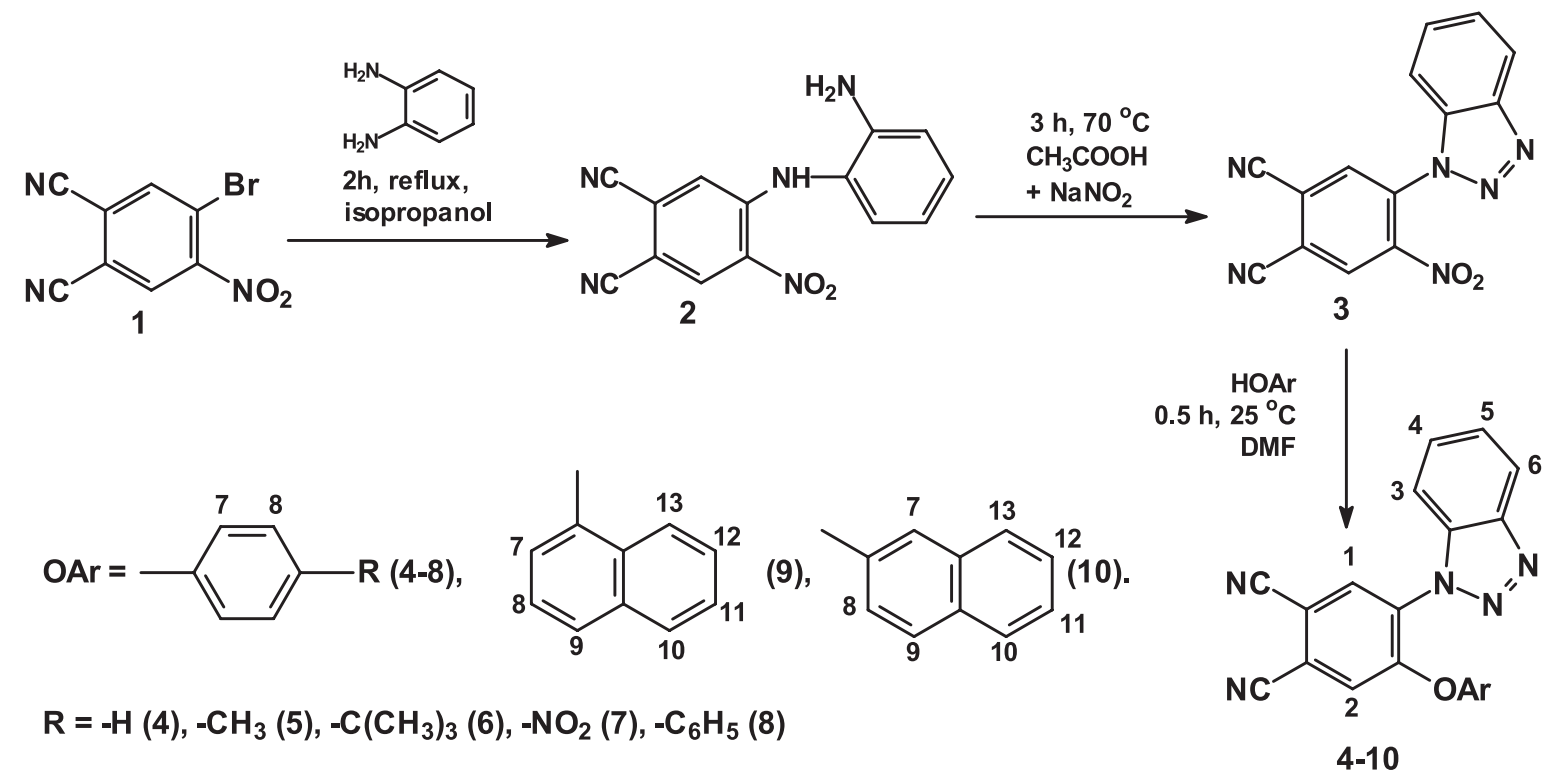

Scheme 1.

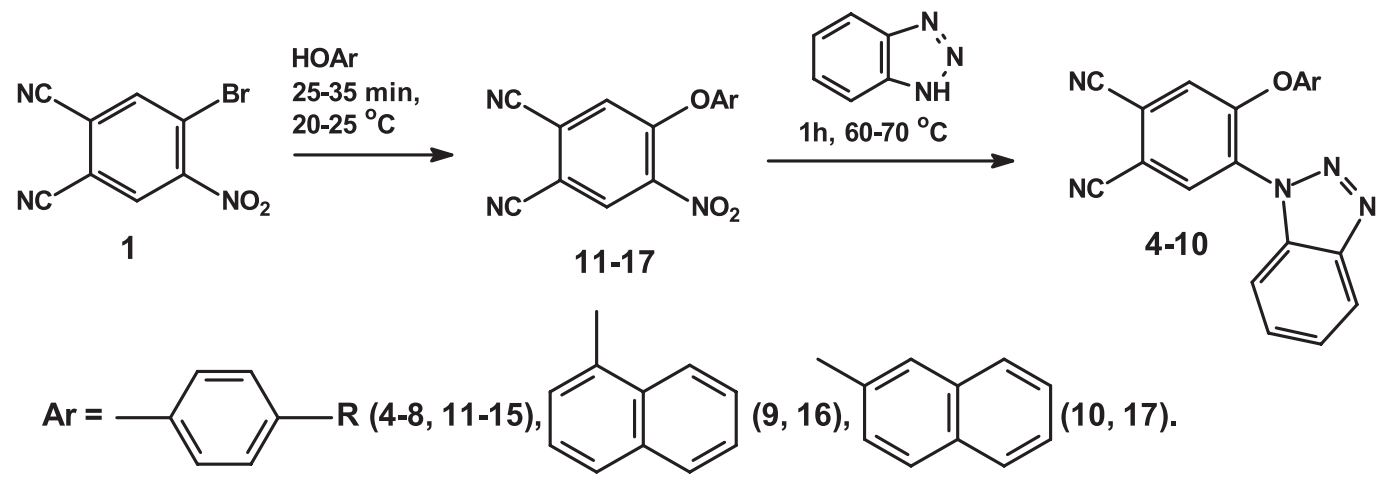

$\mathrm{R}=-\mathrm{H}(4,11),-\mathrm{CH}_{3}(5,12),-\mathrm{C}\left(\mathrm{CH}_{3}\right)_{3}(6,13),-\mathrm{NO}_{2}(7,14),-\mathrm{C}_{6} \mathrm{H}_{5}(8,15)$ 
Table 1. Yields of compounds 4-10 on 4-bromo-5-nitrophthalonitrile 1 (error in determining $\pm 1.2 \%$ ).

\begin{tabular}{|c|c|c|c|}
\hline \multirow[b]{2}{*}{ № } & \multirow[b]{2}{*}{$\mathrm{Ar}$} & \multicolumn{2}{|c|}{ Yields of compounds 4-10 by } \\
\hline & & $\begin{array}{l}\text { three-step } \\
\text { method }^{[15]}\end{array}$ & $\begin{array}{l}\text { two-step } \\
\text { method }\end{array}$ \\
\hline 4 & & 73 & 79 \\
\hline 5 & & 72 & 73 \\
\hline 6 & & 78 & 82 \\
\hline 7 & & 73 & 70 \\
\hline 8 & & 76 & 73 \\
\hline 9 & & 68 & 71 \\
\hline 10 & & 71 & 69 \\
\hline
\end{tabular}

be explained by presence of electron-donating naphthoxysubstituent in ortho-position to nitro group.

Good agreement of physicochemical characteristics of compounds 4-10 synthesized by new method with previously publishing data was found. ${ }^{[15,16]}$ On chromatogram plot of phthalonitrile 10 the single peak was found which proved the formation of individual compound. Peak of molecular ion of the target product with $m / z=387$ was fixed in mass-spectrum of compound $\mathbf{1 0 .}$

Signal of proton of phthalonitrile benzene ring in the ortho-position to benzotriazole fragment $(8.70-8.75 \mathrm{ppm})$ and signal of proton in the ortho-position to aryloxy substituent (8.15-8.10 ppm) are located in low field of NMR spectra of synthesized compounds. Signals of protons of benzene ring of benzotriazolyl substituent (at 8.25-8.18, 7.80-7.83, 7.507.55 and 8.00-8.05 ppm) were also observed.

Vibration bands of cyano, aryloxy and benzotriazolyl substituents were fixed in the IR spectra of phthalonitriles 4-10 therein bands of valent vibrations of $\mathrm{C}_{\mathrm{Ar}}-\mathrm{Br}$ (950-1000 $\left.\mathrm{cm}^{-1}\right)$ and symmetrical $\left(1360-1380 \mathrm{~cm}^{-1}\right)$ and unsymmetrical $\left(1530-1550 \mathrm{~cm}^{-1}\right)$ vibrations of nitro group were disappeared.

\section{Conclusions}

New simplified two-step method for synthesis of 4,5disubstituted phthalonitriles bearing benzotriazolyl and aryloxy-groups was developed. Nucleophilic substitution of bromine atom in 4-bromo-5-nitrophthalonitrile by aryloxy group takes place on the first stage. Interaction between 4-(aryloxy)-5-nitrophthalonitrile and 1- $H$-benzotriazole was carried out on the second stage. Application of this method allows to decrease the total duration of synthesis from 5.5 hours to 1.5 hours. The yields of the target phthalonitriles remain relatively high and are consistent with yields of previously developed three-step procedure.
Acknowledgements. The work was performed with support of the State task for research № 795 (Ivanovo State University of Chemistry and Technology).

\section{References}

1. Shaposhnikov G.P., Kulinich V.P., Maizlish V.E. Modified Phthalocyanines and Their Structural Analogues (Koifman O.I., Ed.) Moscow: Krasand, 2012. 480 p. (in Russ.) [Шапошников Г.П.,Кулинич В.П.,Майзлиш В.Е.Модифuичированные фталочианины и их структурные аналоги (Койфман О.И., ред.) М.: Красанд, 2012. 480 с.]

2. Shaposhnikov G.P., Maizlish V.E. Izv. Vysch. Uchebn. Zaved., Khim. Khim. Tekhnol. 2004, 47(5), 26-35 (in Russ.).

3. The Porphyrin Handbook, Vol. 20. Phthalocyanines: Structural Characterization (Kadish K.M., Smith K.M., Guilard R., Eds.) Academic Press, Elsevier Science (USA), 2003. $300 \mathrm{p}$.

4. Phthalocyanines: Properties and Applications (Leznoff C.C., Lever A.B.P., Eds.) VCH Publishers, Inc. 1989, Vol. 1. 436 p.; 1993, Vol. 2. 436 p.; 1993, Vol. 3. 303 p.; 1996, Vol. 4.524 p.

5. Volkov K.A., Avramenko G.V., Negrimovsky V.M., Lukyanets E.A. Russ. J. Gen. Chem. 2007, 77, 1108-1116.

6. Barkanova S.V., Volkov K.A., Avramenko G.V., Negrimovsky V.M., Lukyanets E.A. J. Porphyrins Phthalocyanines 2006, 10, 555.

7. RF patent № 2385152. Contrasting Agent for MagneticResonance Diagnostics of Tumours. Andronova N.V., Baryshnikov A.J., Vorozhtsov G.N., Dolotova O.V., Kalija O.L., Loshchenov V.B., Luzhkov J.M., Meerovich G.A., Meerovich I.G., Oborotova N. A., Pirogov J.A., Treshchalina E.M., Uchevatkin A.A. Date of publication: 27.03.2010. Bulletin № 9.

8. RF patent № 2257898. Immunoliposomal Form of Photosensitiser. Baryshnikov A.J., Volkov N.N., Ivanov A.V., Ivanov P.K., Ignat'eva E.V., Kortava M.A., Meerovich G.A., Meerovich I.G., Oborotova N.A., Polozkova A.P., Orlova O.L., Sokolova D.V., Sokolova Z.A., Khugaeva O.V. Date of publication: 27.01.2011 Bulletin № 3.

9. Berezina G.R., Znoiko S.A., Maizlish V.E. Izv. Vysch. Uchebn. Zaved., Khim. Khim. Tekhnol. 2012, 55(5), 27-30 (in Russ.).

10. Znoiko S.A., Maizlish V.E., Shaposhnikov G.P., Lebedeva N.Sh., Mal'kova E.A. Russ. J. Phys. Chem. A 2013, 87, 352356.

11. Znoiko S.A., Maizlish V.E., Shaposhnikov G.P., Bykova V.V., Usol'tseva N.V. Liquid Crystals and Their Practical Application 2011, 4(38), 69-79 (in Russ.).

12. Znoiko S.A., Maizlish V.E., Shaposhnikov G.P., Abramov I.G. Izv. Vysch. Uchebn. Zaved., Khim. Khim. Tekhnol. 2012, 55(12), 13-25 (in Russ.).

13. Znoiko S.A., Krivova A.I., Shaposhnikov G.P., Anan'eva G.V., Usol'tseva N.V. Liquid Crystals and Their Practical Application 2012, 4(42), 62-70 (in Russ.).

14. Znoiko S.A., Krivova A.I., Shaposhnikov G.P., Anan'eva G.V., Zharnikova N.V., Usol'tseva N.V. Liquid Crystals and Their Practical Application 2013, 1(43), 7-19 (in Russ.).

15. Abramov I.G., Smirnov A.V., Plakhtinskii V.V., Krasovskaya G.G. Mendeleev Commun. 2002, 12, $72-74$.

16. Znoiko S.A., Kambolova A.S., Maizlish V.E., Shaposhnikov G.P., Abramov I.G., Filimonov S.N. Russ. J. Gen. Chem. 2009, 79, 1735-1740.

17. Shishkina O.V., Maizlish V.E., Shaposhnikov G.P., Lubimtsev A.V., Smirnov R.P., Baran'sky A. Russ. J. Gen. Chem. 1997, 67, 842-845. 